\title{
How risk and uncertainty is used in Supply Chain Management: a literature study \\ A literature study and a preliminary model
}

Bøge Sørensen, Lars

Document Version

Final published version

Publication date:

2004

License

CC BY-NC-ND

Citation for published version (APA):

Bøge Sørensen, L. (2004). How risk and uncertainty is used in Supply Chain Management: a literature study: A literature study and a preliminary model.

Link to publication in CBS Research Portal

\footnotetext{
General rights

Copyright and moral rights for the publications made accessible in the public portal are retained by the authors and/or other copyright owners and it is a condition of accessing publications that users recognise and abide by the legal requirements associated with these rights.

Take down policy

If you believe that this document breaches copyright please contact us (research.lib@cbs.dk) providing details, and we will remove access to the work immediately and investigate your claim.
}

Download date: 26. Apr. 2023 
Copenhagen

Business School

HANDELSHDISKOLEN

How risk and uncertainty is used in

Supply Chain Management: a literature study Lars B. Sørensen

Working Paper No. 02/2004

March, first edition

ISSN 1398-9480 


\title{
How risk and uncertainty is used in supply chain management: a literature study
}

\author{
Lars B. Sørensen
}

Keywords Supply Chain Management, Risk Management, Supply Chain Risk Management

Abstract To comply with Supply Chain Management dogma companies have cut their inventories to a minimum, lead times have been shortened, new suppliers have been chosen and the customer portfolio has been reduced. All of these activities impose a great deal of risk on the firms, jeopardizing the survival of entire supply chains. In this article the author intends to investigate and document the use and meaning of Risk and Uncertainty within journals publishing material on Supply Chain Management and Logistics. Subsequently suggestions for further research are proposed - the integration of Risk Management into the discipline of Supply Chain Design.

\section{Introduction}

Risk Management (RM) is traditionally a term used in the world of finance to describe the vulnerability of investments, justify hedging policies and document the need for insurance (Borge, 2001). The development of the risk measures and management tools available today is well documented in the book "Against the Gods" (Bernstein, 2001). Bernstein describes how $16^{\text {th }}$ and $17^{\text {th }}$ century mathematicians like Bernouilly, de Moivre, Pascal and Fermat developed the mathematical and statistical foundation for financial risk management, primarily from an interest in various types of gambling. Further developments such as portfolio management (Markowitz, 1952) and real options (Black \& Scholes, 1973) are spin-offs from these contributions.

Since the introduction of Supply Chain Management (SCM) (Oliver \& Webber, 1982), companies have reduced inventory, shortened lead times, outsourced non-core activities, and segmented the customer portfolios. Concurrently product life cycles have become shorter, supply chains have become longer and demands from customers have increased significantly in terms of quality, agility and customisation (Schary \& Skjoett-Larsen, 2001). This has left companies more vulnerable to disturbances in the product flow, competency flaws in product development and competition 
between networks, to name but a few risks. The leaner supply chain has definitely increased profitability, but has at the same time introduced a need to better manage the flow of products, the development of relationships and the procedures to design the company's network.

The objective of this paper is to document an extensive literature study on risk and uncertainty within SCM. The literature study is the first step in a research project on risk as a criterion for supply chain design and management.

After introducing the working definition of SCM, a list of relevant journals is presented, and the search method is described. The identified contributions are classified according to orientation in the supply chain, predominant themes, and theoretical and methodological foundation. Based on the literature study, issues in supply chain integration is discussed.

Similar to other literature studies (Bechtel \& Jayaram, 1997), the intended audience falls in two categories: experienced researchers interested in the field looking for research opportunities and the new researchers (e.g. doctoral students) entering the fields of (Business) RM and SCM. Practitioners might benefit from this study in terms of a higher awareness of the importance of identifying, assessing and managing the risks inherent in the cooperation in a supply chain, integrating processes across the boundaries of the individual company.

\section{Supply Chain Management}

Originally, Oliver and Webber (1982) explained the difference between logistics and SCM by the holistic view and strategic nature of SCM, aiming at integrating companies in a system creating a more robust business model. As they point out, the aim is to balance resources and

"that an integrated systems strategy that reduces the level of business vulnerability is developed and implemented" (Oliver \& Webber, 1982, p. 66)

To Stevens (1989) the integration of activities is a prerequisite for SCM. He defines four levels of integration, only the latter being SCM, see Figure 1 below. 


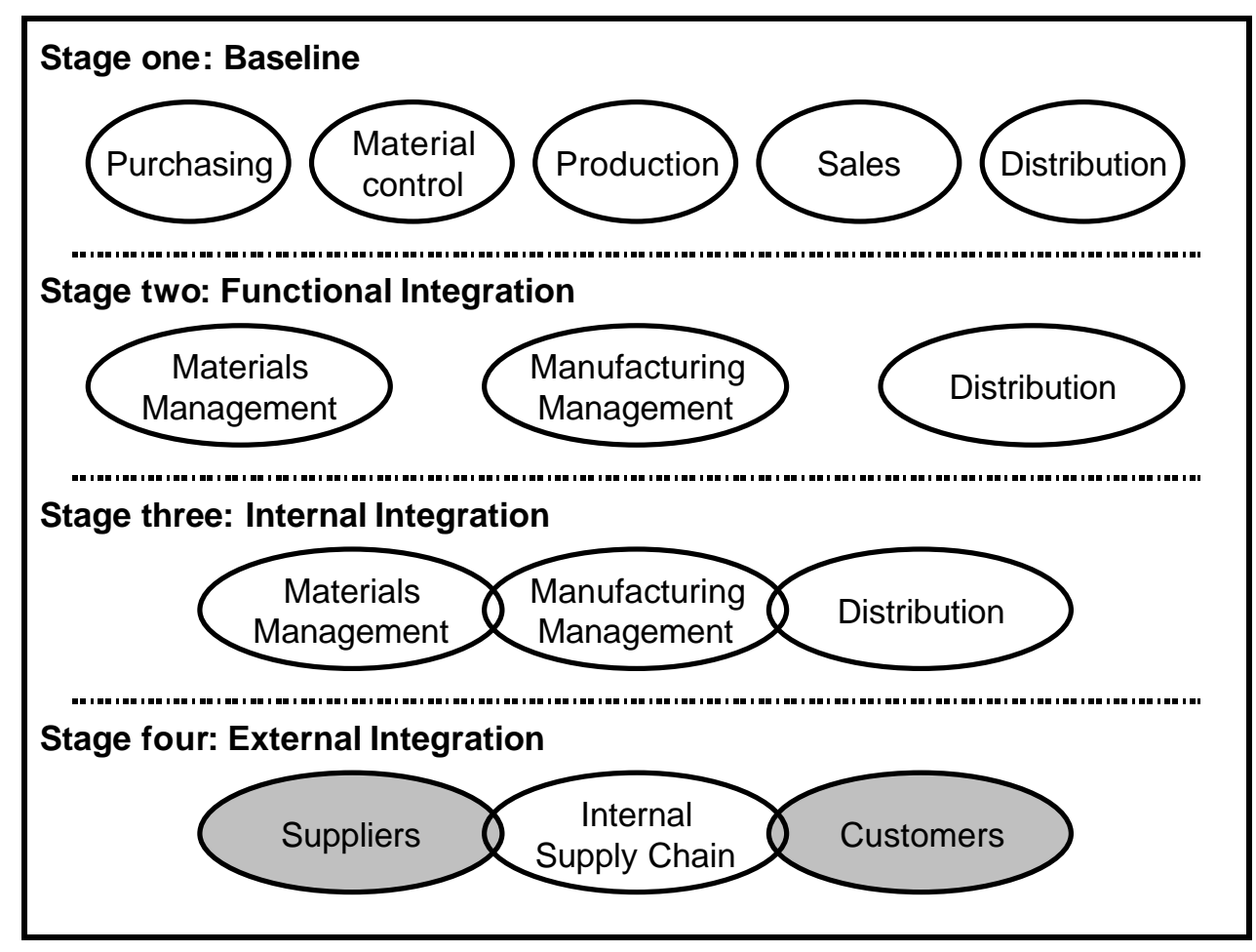

Figure 1: The Integration Model (Stevens, 1989)

In Cooper \& Ellram (1993) SCM is defined as

“...an integrative philosophy to manage the total flow of a distribution channel from the supplier to the ultimate user." (Cooper \& Ellram, 1993)

While this definition more or less equates SCM with the traditional logistics concept, Handfield \& Nichols (1999) define supply chains as encompassing

“...all activities associated with the flow and transformation of goods from the raw materials stage, through to the end users, as well as the associated information flows. Material and information flow both up and down the supply chain. ... [SCM is] the integration of these activities through supply chain relationships, to achieve a sustainable competitive advantage." (Handfield \& Nichols, 1999)

To Mentzer et al. (2001) a supply chain is

" a set of three or more entities (organizations or individuals) directly involved in the upstream and downstream flows of products, services, finances, and/or information from a source to a customer." (Mentzer et al., 2001)

Mentzer and his colleagues distinguish between a "direct supply chain", an "extended supply chain", and an "ultimate supply chain". The direct chain encompasses the focal company, a 
supplier and a customer. The extended chain includes suppliers' suppliers and customers' customers, and the ultimate chain includes all the organizations involved, e.g. third-party logistics providers, financial services providers and providers of management services. They go on and classify the various definitions of SCM into three categories: a management philosophy, an implementation of a management philosophy and a set of management processes.

Harland (1996) divides the definitions into: management of supply relationships, management of inter-business chains, and management of inter-business networks.

Although definitions of SCM vary, they all have three things in common: (1) the focus on the efficient flow of materials, finances and information between firms in the chain/network, (2) the process orientation of the participating firms and (3) the integration of processes across company boundaries. Figure 2 illustrates the author's view of the supply chain.

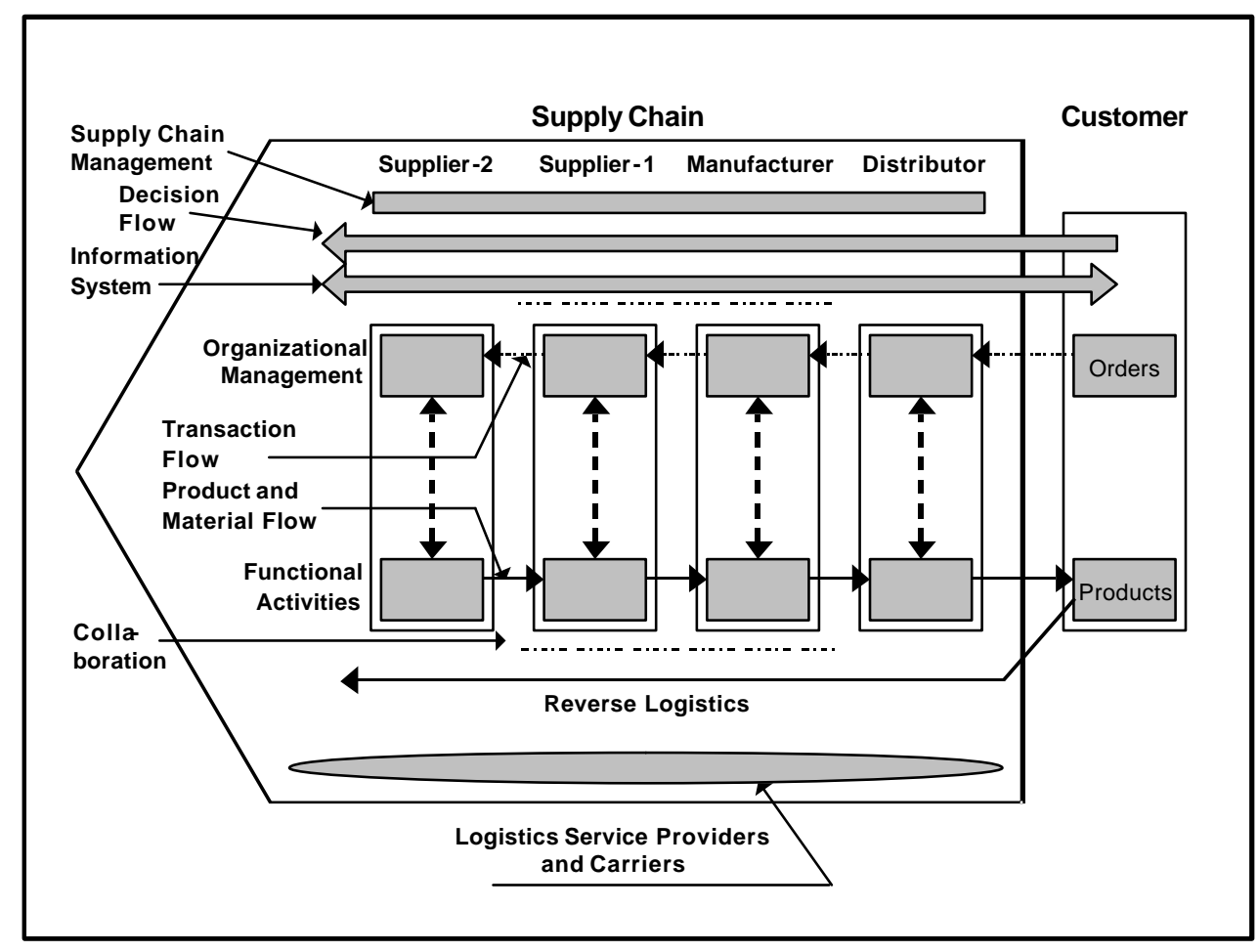

Figure 2: The Global Supply Chain (Schary \& Skjoett-Larsen, 2001, p. 39)

The integration with suppliers and customers come with a price: increased risk. The overall cost reduction obtained through the adjustment of processes across organizational boundaries, the resources invested in integrating socially through frequent interaction and modification of IT (and other) systems to support commonality in reporting is countered by an increase in the risks, e.g. the 
risk of opportunistic behaviour of supply chain partners, increased transparency in operations and vulnerability due to the reliance on fewer suppliers etc.

This wide range of risks points toward an integration of risk into the models/theories used when performing SCM: operating/managing the company and its supply chain partners and developing the network. These issues will be dealt with in later contributions.

\section{Research methodology}

The literature study performed is based on a list of relevant journals identified as a compromise between other literature studies performed within the field (Zsidisin, 2003) and evaluations of the usefulness of journals (Gibson \& Hanna, 2003). The journals investigated fall in three categories, listed in Table 1 below. Since "Supply Chain Risk" is not an established term, the analysis has been performed by reading through the abstracts of all is sues available to the author, looking for articles dealing with Vulnerability, Uncertainty and Risk. The inclusion of an article in the study is based on the subjective choice made by the author.

After analysing the list of relevant journals, the quality of this search is tested by performing a cross-database search using the phrase "Logistics" or "Supply Chain" and combining that with "Vulnerability", "Uncertainty" or "Risk". These six combinations are tested in all available e databases: ABI/INFORM, Business Source Premier, EMERALD, JSTOR and Science Direct. The number of relevant hits will determine the "completeness" of the list of relevant journals mentioned above.

The final step in the analysis is to identify themes, defined as a collection of at least three articles focusing on the same problem or phenomenon. The articles are grouped according to the problem investigated or phenomenon described. The process is repeated until as many articles as possible belong to at least one theme, and the themes themselves are constant. Between iterations the themes identified are evaluated and themes are potentially redefined or merged with other themes. The method is very subjective, but is deemed acceptable as a means to describe trends in the published material. The analysis is performed first with each of the three journal categories and then for the entire collection of articles. The purpose of this analysis is to document if the use of risk and uncertainty within the three sub-disciplines differ, and subsequently if there are any themes that cut across the journal categories.

\footnotetext{
${ }^{1}$ Alternatively in one step using the expression “('logistics' OR 'supply chain') AND ('vulnerability' OR 'uncertainty' OR 'risk')".
} 
Table 1: List of relevant journals

\begin{tabular}{|c|c|c|}
\hline Journal Name & Abbrev. & Period investigated \\
\hline \multicolumn{3}{|l|}{ Logistics } \\
\hline European Journal of Purchasing and Supply Management ${ }^{2}$ & EJPSM & $1994[$ vol 1] - 2002 [vol 8] \\
\hline International Journal of Logistics Management & IJLM & $1990[$ vol 1] - 2002 [vol 13] \\
\hline International Journal of Logistics: Research and Application & IJL-RA & $1999[\mathrm{vol} \mathrm{2}]-2002[\mathrm{vol} \mathrm{5}]^{3}$ \\
\hline International Journal of Physical Distribution \& Logistics Management & IJPDLM & 1994 [vol 24] - 2003 [vol 33] \\
\hline International Journal of Purchasing and Materials Management $^{4}$ & IJPMM & 1985 [vol 21] - 1998 [vol 34] \\
\hline Journal of Business Logistics & JBL & $1978[\operatorname{vol~1]}-2003[\mathrm{vol} 24]$ \\
\hline Journal of Purchasing and Supply Management $^{5}$ & JPSM & 2003 [vol 9] - 2003 [vol 9] \\
\hline Journal of Supply Chain Management $^{6}$ & JSCM & 1999 [vol 35] - 2003 [vol 39] \\
\hline Supply Chain Management: An International Journal & SCM-IJ & $1996[\mathrm{vol} \mathrm{1}]-2003$ [vol 8] \\
\hline Supply Chain Management Review & SCMR & $2000[\mathrm{vol} \mathrm{4}]-2003[\mathrm{vol} \mathrm{7]}$ \\
\hline \multicolumn{3}{|c|}{ Operations Management } \\
\hline Interfaces & I & $1971[\operatorname{vol~1]}-2002$ [vol 32] \\
\hline International Journal of Production Economics & IJPE & 1991 [vol 22] - 2003 [vol 85] \\
\hline International Journal of Operations \& Production Management & IJOPM & $1980[$ vol 1] - 2003 [vol 23] \\
\hline Journal of Operations Management & JOM & $1980[\mathrm{vol} \mathrm{1}]-2003[\mathrm{vol} 21]$ \\
\hline \multicolumn{3}{|l|}{ Management } \\
\hline California Management Review & CMR & $1980[\mathrm{vol} \mathrm{22]}-2003$ [vol 45] \\
\hline Decision Science & DS & 1985 [vol 16] - 2002 [vol 33] \\
\hline European Management Journal & EMJ & $1982[\operatorname{vol~1]}-2003[\mathrm{vol} 21]$ \\
\hline Harvard Business Review & HBR & $1990[\mathrm{vol} \mathrm{68]}-2003[\mathrm{vol} \mathrm{81]}$ \\
\hline Industrial Marketing Management & IMM & 1985 [vol 14] - 2003 [vol 32] \\
\hline Journal of Occupational Behaviour $^{7}$ & JOCB & $1980[$ vol 1] - $1987[\mathrm{vol} \mathrm{8]}$ \\
\hline Journal of Organizational Behavior $^{8}$ & JORB & $1988[\mathrm{vol} \mathrm{9}]-2003$ [vol 24] \\
\hline Scandinavian Journal of Management & SJM & $1988[\mathrm{vol} \mathrm{4}]-2003[\mathrm{vol} \mathrm{19}]$ \\
\hline Sloan Management Review & SMR & $1970[\mathrm{vol} \mathrm{12}]-2000$ [vol 42] \\
\hline
\end{tabular}

\section{Results}

The results of the literature study are presented in the following section. Each of the articles is classified according to orientation (Supply, Internal, Demand and/or Network) and strategic level (Strategy and/or Operational), and the explicit use of theory/framework is listed as well. The chosen categorizations are determined with the implicit structure of a supply chain and the standard structure of an academic article in mind. Some of the contributions might not "fit" the categories, and these will be identified with the symbol '-'.

Besides the categorizations mentioned above, attention is given the use of or reference to RM. The identification, assessment and management of risks are of primary interest in this study; contributions that fall within this domain will receive special attention, and will be described in

\footnotetext{
2 The journal changed name to "Journal of Purchasing and Supply Management" in 2003.

${ }^{3}$ Last 12 months available as abstracts only.

4 The journal changed name to "Journal of Supply Chain Management" in 1999.

${ }^{5}$ Previously "European Journal of Purchasing and Supply Management".

${ }^{6}$ Previously "International Journal of Purchasing and Materials Management".

${ }^{7}$ The journal changed name to "Journal of Organizational Behavior" in 1988.

${ }^{8}$ Previously "Journal of Occupational Behaviour".
} 
further detail. Finally, the underlying themes will be analysed, first for each category of journal, and subsequently for all articles collectively.

\section{Logistics and SCM journals}

The search in bgistics and SCM journals resulted in 36 matches. Categorizing the contributions according to the orientation revealed a distinct over-representation on the upstream side, and a surprising lack of focus on the network level. The majority of contributions are dealing with operational issues, especially the journals "International Journal of Logistics: Research and Application", "International Journal of Physical Distribution \& Logistics Management" and "Journal of Business Logistics". In contrast, the journal "Supply Chain Management Review" has only articles with strategic orientation.

Explicit use of theory is almost absent, although an important exception is Svensson (2000; 2001; 2002a; 2002b; 2002c; 2002d), who is using marketing channels in all his contributions. Other examples of explicit use of theory are the articles "Proactive Supply Management: The Management of Risk” (Smeltzer \& Siferd, 1998), “An Agency Theory Investigation of Supply Risk Management" (Zsidisin \& Ellram, 2003) and "Effectively managing vertical supply relationships: a risk management model for outsourcing" (Lonsdale, 1999), using resource-based theory and transaction cost economics, agency theory, and resource-based theory, respectively. Finally, there are a few articles using modelling.

As for explicit references to RM, only three articles could be identified: "Risk in supply networks" (Harland, Brenchley, \& Walker, 2003), "Effectively managing vertical supply relationships: a risk management model for outsourcing" (Lonsdale, 1999) and "Purchasing organization involvement in risk assessments, contingency plans, and risk management: an exploratory study" (Zsidisin, Panelli, \& Upton, 2000). As indicated by the titles, all three articles deal with the supply side of the network only. Albeit SCM is about inter-organizational business processes and fulfilment of the customer demand, there is a lack of focus on the customer side.

Of the six articles dealing with activities internal to the company, two are dealing with demand uncertainty and inventory management, two are concerned with planning of operations, and the last two are dealing with demand uncertainty and facility location analysis and strategic planning, respectively. Table 2 below shows the articles found, their orientation, strategic level and explicit theories referenced. 
Table 2: Classification of articles published in SCM/Logistics journals

\begin{tabular}{|c|c|c|c|c|c|c|c|c|}
\hline \multirow{2}{*}{ Journal } & \multirow{2}{*}{ Article } & \multicolumn{4}{|c|}{ Orientation } & \multicolumn{2}{|c|}{ Level } & \multirow{2}{*}{ Explicit Theory } \\
\hline & & $\mathbf{S}$ & I & $\mathbf{D}$ & $\mathbf{N}$ & $\mathbf{S}$ & $\mathbf{O}$ & \\
\hline EJPSM & Ottesen \& Gronhaug, 2002 & $\checkmark$ & & & & $\checkmark$ & & None \\
\hline \multirow{2}{*}{ IJLM } & Ho \& Carter, 1994 & & $\checkmark$ & & & & $\checkmark$ & None \\
\hline & Sheffi, 2001 & " & & ' & & $\checkmark "$ & & "Utility \\
\hline \multirow{2}{*}{ IJL-RA } & $\begin{array}{ll}4 . & \text { Svensson, } 2001\end{array}$ & $\checkmark$ & & $\sqrt{ }$ & & & $\checkmark$ & Marketing Channels \\
\hline & Svensson, $2002 \mathrm{~b}$ & $\checkmark$ & & $\checkmark$ & & & $\checkmark n$ & Marketing Channels \\
\hline \multirow{7}{*}{ IJPDLM } & Boronico \& Bland, 1996 & & $\checkmark$ & & & & $\checkmark$ & Modeling \\
\hline & Koutsoukis et al., 2000 & $\sqrt{2}$ & $\sqrt{ }$ & $\checkmark$ & & & $\sqrt{2}$ & Modeling \\
\hline & 8. $\quad$ Svensson, 2000 & " & & & & & ("vi" & Marketing Channels \\
\hline & 9. Svensson, $2002 a$ & 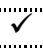 & & 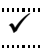 & & & $\checkmark$ & Marketing Channels \\
\hline & 10. Svensson, $2002 \mathrm{c}$ & 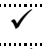 & & 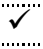 & & & 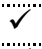 & Marketing Channels \\
\hline & 11. van der Horst \& Beulens, 2002 & $\sqrt{2}$ & & & & & $\sqrt{2}$ & None \\
\hline & 12. Wilding $1998 *$ & "'v" & & " $y$ & & & " & "None \\
\hline \multirow{5}{*}{ IJPMM } & 13. Carter, Vickery, \& D'Itri, 1993 * & $\sqrt{ }$ & & & & & $\checkmark$ & Modeling \\
\hline & 14. Pilling \& Z hang $1992 *$ & $\sqrt{2}$ & & & & $\checkmark$ & $\sqrt{2}$ & None \\
\hline & 15. Smeltzer \& Siferd, 1998 & $\sqrt{2}$ & & & & & $\sqrt{2}-190$ & TCE, RBT \\
\hline & 16. Templin \& Noffsinger, 1994 & " & & & & & " & None \\
\hline & 17. Tullous \& Munson, 1991 & $\checkmark y$ & & & & & $\checkmark$ & "None" \\
\hline \multirow{9}{*}{ JBL } & 18. Copacino \& Lapide, 1984 * & $\sqrt{ }$ & & $\sqrt{ }$ & & & $\sqrt{ }$ & None \\
\hline & 19. Lau, 1989 & & $\checkmark "$ & & & & " & None \\
\hline & 20. Menachof, 1996 & - & n."- & - & - & & 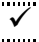 & None \\
\hline & 21. Meshkat \& Ballou, 1996 & & $\sqrt{r}$ & & & & $\sqrt{r}$ & None \\
\hline & 22. $\quad$ Schwarz \& Wenig, 2000 & 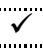 & & $\checkmark$ & & & 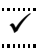 & None \\
\hline & 23. Speh \& Wagenheim, 1978 & & & $\checkmark$ & & & $v$ & None \\
\hline & 24. Vidal \& Goetschalkx, 2000 & & & & $v "$ & & 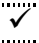 & Modeling \\
\hline & 25. Wood, $1985 * \cdots$ & - & - & - & - & & $\checkmark$ & None \\
\hline & Zinszer, 1983 & & $\checkmark$ & & & & $\sqrt{ }$ & None \\
\hline JPSM & 27. Harland, Brenchley, \& Walker, 2003 & $\checkmark$ & & $\checkmark$ & & $\checkmark$ & $\checkmark$ & None \\
\hline \multirow{2}{*}{ JSCM } & 28. $\quad$ Zsidisin, 2003 & $\checkmark$ & & & & & $\checkmark$ & None \\
\hline & 29. Zsidisin \& Ellram, 2003 & $\checkmark$ & & & & $\checkmark$ & & Agency Theory \\
\hline \multirow{3}{*}{ SCM-IJ } & 30. Lonsdale, 1999 & $\sqrt{ }$ & & & & $\checkmark$ & $\checkmark$ & RBT \\
\hline & 31. Svensson, 2002 & $\checkmark y$ & & $\checkmark$ & & "'s" & $\checkmark v$ & Marketing Channels \\
\hline & 32. Zsidisin, Panelli, \& Upton, 2000 & $\checkmark$ & & & & $\checkmark$ & $\checkmark$ & None \\
\hline \multirow{4}{*}{ SCMR } & 33. Geary, Childerhouse, \& Towill, $2002 *$ & $\sqrt{ }$ & & $\sqrt{ }$ & & $\sqrt{2}$ & & None \\
\hline & 34. Lee \& Wolfe, 2003 & "aln' & & ' & & 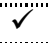 & & "TQM" \\
\hline & 35. Martha \& Subbakrishna, 2002 & $\checkmark y$ & & & & "'ll' & & None \\
\hline & 36. Simchi-Levi, Snyder, \& Watson, 2002 & $\checkmark$ & & & & $\checkmark$ & & None \\
\hline
\end{tabular}

Classifying the articles based on problem/subject/theme reveals a certain degree of overlap, as even after a couple of iterations, the articles still "belong" to more themes. Accepting the ambiguity of the themes supports the notion of uncertainty/risk as an underlying theme in many areas.

The most predominant themes are "Vulnerability in physical flows" and "Supply Management", the former dominated by Svensson, the latter characterized by many contributors. These two are predominant in the sense that the theme was defined in the first iteration, while the theme "Improving Techniques for Operations" is the result of several iterations. Of the 36 articles, 30 were assigned to the five themes identified. The remaining six articles do not "fit" the themes identified (marked ' $*$ ' in the table), and since there is no commonality between the six, they are kept unassigned until the re-analysis of the total portfolio of articles later. 
Table 3 below shows the identified themes and the articles assigned to them.

Table 3: Themes identified in SCM/Logistics journals

\begin{tabular}{|l|l|}
\hline Theme & Article No \\
\hline Improving Techniques for Operations & $2,6-7,11,19-22,24,26,30$ \\
\hline Risk Management & $27,30,32$ \\
\hline Securing the Supply Chain & $3,34-36$ \\
\hline Supply Management & $1,6,15-17,28-29,32$ \\
\hline Vulnerability in Physical Flows & $4-5,8-10,23,31$ \\
\hline
\end{tabular}

\section{Operations Management journals}

The search in the four OM journals resulted in 44 matches, of which almost all are focusing on operational issues. Also the method used is quite uniform, as the vast majority of articles use mathematical modelling. Of the few articles not using mathematical modelling, only one, "Strategic Sourcing, Vertical Integration, and Transaction Cost" (Walker, 1988), makes explicit references to theory, namely resource-based theory and transaction cost economics.

The orientation of the articles within this category differs from the previous category and shows more diversification, as more articles have internal orientation (22) than upstream (16) or downstream (12). Two articles, "A dynamic game model for distribution problems with nonstochastic uncertainty" (Blanchini, Rinaldi, \& Ukovich, 1996) and "Simulation of supply chain behaviour and performance in an uncertain environment" (Petrovic, 2001), are oriented towards the network level.

Within this category only partial contributions to risk management in supply chains have been identified. All five articles identified, "Purchasing, Risk and Logistics: A Neglected Combination?" (Wright, 1980), “A methodology for the vulnerability analysis of just-in-time production systems" (Albino \& Garavelli, 1995), "Risk analysis and assessment in network environments: A dyadic case study" (Hallikas, Virolainen, \& Tuominen, 2002), "Profit and risk evaluation in customer driven engineering and manufacturing" (Muntslag, 1994), and "Market vulnerability in process industries" (Zaidman, 1994) focus on assessment, not identification or management of risks.

Other themes emerging from the analysis are identical to the previous category despite our attempts to "disregard" the themes previously identified. Of the five themes identified in the previous category, three are reused and no new ones are added. The hit rate assigning articles to themes is similar to the previous category, as 36 of the 44 articles are assigned. Assigning more articles to fewer categories call for a further subdivision of the three categories, but attempts on this has been unsuccessful. As for the previous category, the remaining articles do not represent any 
commonality, and cover issues as diverse as e.g. safety in rail transportation of dangerous commodities (Swoveland, 1987) and risks incurring in companies producing highly seasonal products (Vörös, 1999).

All the articles are classified in Table 4 and assigned themes in Table 5.

Table 4: Classification of articles published in Operations Management journals

\begin{tabular}{|c|c|c|c|c|c|c|c|c|}
\hline \multirow{2}{*}{ Journal } & \multirow{2}{*}{ Article } & \multicolumn{4}{|c|}{ Orientation } & \multicolumn{2}{|c|}{ Level } & \multirow{2}{*}{ Explicit Theory } \\
\hline & & $\mathbf{S}$ & I & $\mathbf{D}$ & $\mathbf{N}$ & $\mathbf{S}$ & $\mathbf{O}$ & \\
\hline \multirow{2}{*}{ I } & 37. Swoveland, $1987 *$ & - & - & - & - & & $\checkmark$ & None \\
\hline & 38. Walker, 1988 & "ral & & & & " & & "'RBT, TCE' \\
\hline \multirow{4}{*}{ IJOPM } & 39. $\quad$ Baker, 1986 & & $\checkmark$ & & & & $\checkmark$ & None \\
\hline & 40. Callarman \& Hamrin, 1984 & & $\sqrt{2}$ & 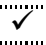 & & & $\checkmark$ & Modeling \\
\hline & 41. Newman, Hanna, \& Maffei, 1993 & 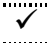 & & & & & $\checkmark r$ & None \\
\hline & 42. Wright, 1980 & 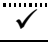 & & & & " & & "None" \\
\hline \multirow{28}{*}{ IJPE } & 43. Albino \& Garavelli, 1995 & $\checkmark$ & & $\checkmark$ & & & $\checkmark$ & Modeling \\
\hline & 44. Bartezzaghi \& Verganti, 1995 & & & $\sqrt{2}-190$ & & & 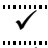 & Modeling \\
\hline & 45. Bartezzaghi, Verganti,\& Zotteri, 1999 & & (n) & & & & 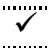 & Modeling \\
\hline & 46. Blanchini, Rinaldi, \& Ukovich, 1996 & & & & $v "$ & & "ral' & Modeling \\
\hline & 47. Dolgui \& Ould-Louly, 2002 & & $\sqrt{2}$ & & & & $\sqrt{2}$ & Modeling \\
\hline & 48. Gong \& Sun, 1995 & & 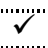 & & & & $v "$ & Modeling \\
\hline & 49. Gupta, Gerchak, \& Buzacott, 1992 & & "ln' & & & 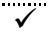 & "ran' & Modeling \\
\hline & 50. Güllü, Onol, \& Erkip, 1999 & 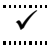 & & & & & 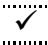 & Modeling \\
\hline & 51. Hallikas, Virolainen, \& Tuominen, 2002 & $\checkmark$ & & 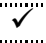 & & $\sqrt{2}-190$ & 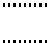 & None \\
\hline & 52. Jang \& Liu, 1993 & & (n) & (3) & & (3) & (3) & Modeling \\
\hline & 53. Jeunet \& Jonard, 2000 & " ne" & & & & & "ran' & Modeling \\
\hline & 54. Johansen, 1999 & & & $\checkmark$ & & & $\sqrt{2}$ & Modeling \\
\hline & 55. Kelle \& Miller, 2001" & (n) & & & & (n) & (n) & Modeling \\
\hline & 56. Korpela et al., 2002 & & & 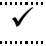 & & (3) & 'T"' & Modeling \\
\hline & 57. Lau, Lau, \& Willett, $2000 *$ & & & (n) & & & (n) & Modeling \\
\hline & 58. Matsuura, Tsubone, \& Kataoka, 1995 & & $\checkmark r$ & & & & $\checkmark r$ & Modeling \\
\hline & 59. Muntslag, 1994 & & 2 & & & & "ren" & Modeling \\
\hline & 60. Murthy \& Ma, $1991 *$ & & (n) & & & & 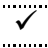 & None \\
\hline & 61. Petrovic, $2001 *$ & & & & (n).... & & (n) & Modeling \\
\hline & 62. Petrovic \& Petrovic, 2001 & (3) & & & & & (3) & Modeling \\
\hline & 63. Tang \& Grubbström, 2002 & & 2 & & & & 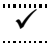 & Modeling \\
\hline & $\begin{array}{l}\text { 64. van der Vaart, de Vries, \& Wijngaard, } \\
1996\end{array}$ & $\checkmark$ & & & & & $\checkmark$ & None \\
\hline & 65. $\quad$ van Dorp \& Duffey, 1999 & & 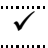 & & & & " nen" & Monte Carlo \\
\hline & 66. Vörös, $1999 *$ & & 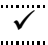 & & & & (n) & Modeling \\
\hline & 67. Wenig, 1999 & & & (n) & & & 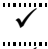 & Modeling \\
\hline & 68. ' Zaidman, 1994 & & & 2 & & 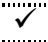 & " ne" & Modeling \\
\hline & 69. Zimmer, 2002 & " ne" & & & & & "ren' & Modeling \\
\hline & 70.' Zäpfel, 1996 & & 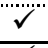 & & & & $\checkmark$ & Modeling \\
\hline \multirow{10}{*}{$\mathrm{JOM}$} & 71. Callen \& Sarath, $1995 *$ & & $\checkmark$ & & & & $\checkmark$ & Modeling \\
\hline & 72. $\quad$ Denzler, Boe, \& Duplaga, 1987 & & 2 & & & & " ne" & Modeling \\
\hline & 73. Etienne, 1987 & (3) & 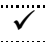 & & & & (") & Modeling \\
\hline & 74. Hill \& Vollmann, 1986 & 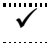 & & & & & $\checkmark r$ & Modeling \\
\hline & 75. Kadipasaoglu \& Sridharan, 1995 & 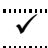 & $\sqrt{3}$ & & & & $v "$ & Modeling \\
\hline & 76. Lewis, $2003 *$ & & 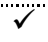 & 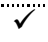 & & & 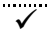 & None" \\
\hline & 77. Pagell \& Krause, $1999 *$ & $r$ & $\checkmark$ & $\checkmark$ & & & $\checkmark$ & None \\
\hline & 78. Schmitt, 1984 & & $\sqrt{3}$ & & & & 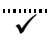 & Modeling \\
\hline & 79. Treleven \& Schweikhart, 1988 & 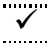 & & & & 2 & 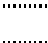 & "None" \\
\hline & 80. Zhao \& Lee, 1993 & & 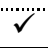 & & & & 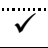 & Modeling \\
\hline
\end{tabular}


Table 5: Themes identified in OM journals

\begin{tabular}{|l|l|}
\hline Theme & Article No \\
\hline Improving Techniques for Operations & $39-41,44-50,52-54,56,58,62-65,67,70,72-73,75,78,80$ \\
\hline Risk Management & $42-43,51,59,68$ \\
\hline Supply Management & $38,42,55,64,69,74,79$ \\
\hline
\end{tabular}

\section{Management journals}

The search in the selected management journals resulted in 43 matches, see Table 6 below.

Table 6: Classification of articles published in Management journals

\begin{tabular}{|c|c|c|c|c|c|c|c|c|}
\hline \multirow{2}{*}{ Journal } & \multirow{2}{*}{ Article } & \multicolumn{4}{|c|}{ Orientation } & \multicolumn{2}{|c|}{ Level } & \multirow{2}{*}{ Explicit Theory } \\
\hline & & $\mathbf{S}$ & I & $\overline{\mathbf{D}}$ & $\mathbf{N}$ & $\mathbf{S}$ & $\mathbf{O}$ & \\
\hline \multirow{3}{*}{ CMR } & 81. Grabowski \& Roberts, $1997 *$ & - & - & - & - & $\checkmark$ & & None \\
\hline & 82. Johnson, 2001 & 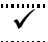 & & 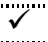 & & (n) & & "None" \\
\hline & 83. Lee, $2002 *$ & $\checkmark$ & & $\sqrt{2}$ & & $\checkmark$ & & None \\
\hline \multirow{17}{*}{ DS } & $\begin{array}{ll}\text { 84. } & \text { Arcelus, Pakkala, \& Srinivasan, } \\
2002 *\end{array}$ & $\checkmark$ & & & & & $\checkmark$ & Modeling \\
\hline & 85. Ballestero, 2002 & & $\checkmark$ & & & & $\sqrt{2}$ & Modeling \\
\hline & 86. Ballou \& Pazer, 1987 & & $\checkmark$ & & & & 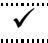 & None \\
\hline & 87. Christy \& Kanet, 1988 & "ln' & $\checkmark v$ & & & & "ln' & "None" \\
\hline & 88. Dillinger, Stein, \& Mizzi, 1992 & - & -" & "no." & - & & 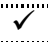 & "None" \\
\hline & 89. Ghosh \& Ray, 1992 & 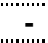 & - n & - & - & & 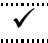 & None \\
\hline & 90. Ghosh \& Ray, 1997 & - & - n & - & - & & (n) & None \\
\hline & 91. Ghosh, 1994 & "-"- & "'-"' & -"- & -"- & & " & "None \\
\hline & 92. Graves \& Ringuest, 1991 & $\sqrt{2}$ & $\cdots \cdots$ & & & & $\sqrt{2}$ & None \\
\hline & 93. Havlena \& DeSarbo, 1991 * & & - & $\checkmark$ & -..." & & $\checkmark$ & None \\
\hline & 94. Krueger \& Dickson, 1994 & $\begin{array}{ll}-1 \\
-1\end{array}$ & - n & $\begin{array}{ll}-1 \\
-1\end{array}$ & (n) & - n & 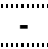 & None \\
\hline & 95. Lee, 1997 & - & - & - & - & - & - & $\begin{array}{l}\text { Prospect } \\
\text { Modeling }\end{array}$ \\
\hline & 96. $\quad$ Lin \& Krajewski, 1992 & & 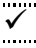 & ".'.". & 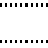 & & 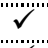 & Modeling \\
\hline & 97. Marshall \& Narasimhan, 1989 & - & - & - & - & $\sqrt{2}$ & $\sqrt{2}$ & Decision theory \\
\hline & 98. Noori \& Keller, 1986 & & 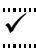 & & w. & & $\checkmark$ & None \\
\hline & 99. $\quad$ Sridharan \& Berry, 1990 & & 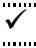 & 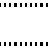 & & & (n) & None \\
\hline & 100. Wedel \& DeSarbo, $1993 *$ & - & - & - & - & & 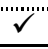 & None \\
\hline \multirow{2}{*}{ EMJ } & 101. Collis, $1992 *$ & - & - & - & - & $\checkmark$ & & None \\
\hline & 102. Noy \& Ellis, $2003 *$ & - & - & - & - & $\checkmark$ & & None \\
\hline \multirow{6}{*}{ HBR } & 103. Bernstein, $1996 *$ & - & - & - & - & - & - & None \\
\hline & 104. Fisher et al., 1994" & & & (3).... & & ............. & 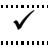 & None \\
\hline & 105. Hecht \& Morici, $1993 *$ & - & - & - & - & - & - & None \\
\hline & 106. Sells, $1994 *$ & - & - & - & - & - & - & None \\
\hline & 107. Simons, $1999 *$ & & $\checkmark$ & & & $\sqrt{2}$ & & None \\
\hline & 108. Watkins \& Bazerman, 2003 & $\sqrt{2}$ & & $\checkmark n$ & & $\sqrt{2}$ & & None" \\
\hline \multirow{6}{*}{ IMM } & 109. Bunn \& Liu, $1996^{*}$ & & & $\checkmark$ & & & $\checkmark$ & None \\
\hline & $\begin{array}{l}\text { 110. Henthorne, LaTour, \& Williams, } \\
1993 *\end{array}$ & & $\checkmark$ & & & & $\checkmark$ & None \\
\hline & 111. Meldrum \& Milllman, $1991 *$ & & & 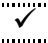 & & $\sqrt{2}$ & 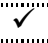 & None \\
\hline & 112. Polk, Plank, \& Reid, 1996 *' & & & $\sqrt{3}$ & & & 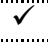 & "None \\
\hline & 113.'Schill, 1985 & 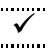 & & (n) & & 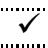 & & None \\
\hline & 114. Westbrook, $1996 *$ & & & $\checkmark$ & & & $\checkmark$ & None \\
\hline JOCB & 115. Clegg \& Fitter, $1981 *$ & & $\checkmark$ & & & & $\checkmark$ & Organizational theory \\
\hline JORB & \multicolumn{8}{|c|}{ None } \\
\hline SJM & \multicolumn{8}{|c|}{ None } \\
\hline \multirow[t]{4}{*}{ SMR } & 116. Allaire \& Firsirotsu, $1989 *$ & & $\checkmark$ & & & $\checkmark$ & & None \\
\hline & 117. Bowman, $1980 *$ & - & - & - & $-\cdot$ & $\sqrt{2}+2$ & & None \\
\hline & 118. Bowman, 1982 * & - & (n) & (-)."- & - & (n) & & None \\
\hline & 119. Clemons, $1995 *$ & & $\checkmark$ & & & $\sqrt{-1}$ & & None \\
\hline
\end{tabular}




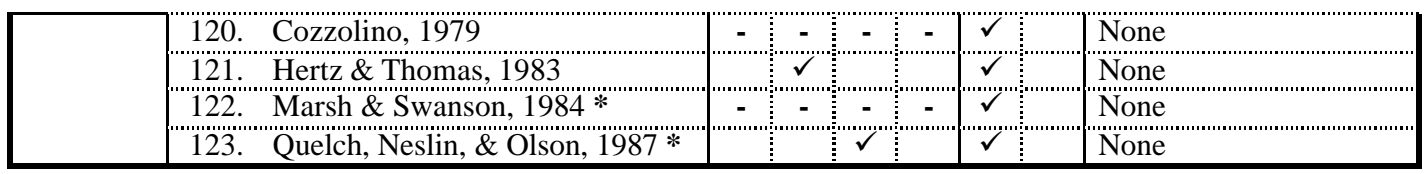

A relatively large proportion of the articles do not fit into the categories. Five articles do not fit neither the 'Orientation' nor the 'Level' classification, 18 articles do not fit 'Orientation'. Of the nine journals, two do not have any relevant articles. The distribution of strategic/operational is quite even over the group, but most journals have a bias. The journals "California Management Review", "European Management Journal" and "Sloan Management Review" have a strategic orientation, whereas "Decision Science" is focused towards operational issues. In contrast, there is no apparent emphasis on the supply chain orientation across journals. There are no articles in the 'Network' classification, but a quite mixed picture on the other three classifications, fewest in 'Supply'. Again the explicit use of theory is quite scarce; four articles are using modelling, and prospect theory and decision heory are referenced in one article each. Finally, the article in "Journal of Occupational Behavior" makes reference to organizational theory.

Also references to RM are quite scarce. In "Learning From Toys: Lessons In Managing Supply Chain Risk From The Toy Industry" (Johnson, 2001) only the management part is addressed, whereas the article "Decision and Risk Analysis in a New Product and Facilities Planning Problem" (Hertz \& Thomas, 1983) is focusing on the analysis part. The article "Predictable Surprises: The Disasters You Should Have Seen Coming” (Watkins \& Bazerman, 2003) is the only contribution dealing with all three phases: identification, assessment and management.

The analysis for themes revealed a new one, Risk Preference', as well as two already identified: 'Improving Techniques for Operations' and 'Risk Management'. The number of articles not assigned to a theme is quite high, 23. Table 7 below contains the themes identified and the articles assigned to them.

Table 7: Themes identified in Management journals

\begin{tabular}{|l|l|}
\hline Theme & Article No \\
\hline Improving Techniques for Operations & $85-88,92,96-99,104,113,120$ \\
\hline Risk Management & $82,108,121$ \\
\hline Risk Preference & $89-91,94-95$ \\
\hline
\end{tabular}




\section{Cross-database search}

The cross-database search resulted in only 13 new articles, collected from as many as 10 journals. The author therefore concludes that the search in the listed journals is as complete as could be expected.

Table 8: Classification of articles published in other journals

\begin{tabular}{|c|c|c|c|c|c|c|c|}
\hline \multirow{2}{*}{ Article } & \multicolumn{4}{|c|}{ Orientation } & \multicolumn{2}{|c|}{ Level } & \multirow{2}{*}{ Explicit Theory } \\
\hline & $\mathbf{S}$ & $\mathbf{I}$ & $\mathbf{D}$ & $\mathbf{N}$ & $\mathbf{S}$ & $\mathbf{O}$ & \\
\hline 124. Agrawal \& Seshadri, 2000 & $\checkmark$ & & & & & $\checkmark$ & Modeling \\
\hline 125. Bensaou \& Anderson, 1999 & $\checkmark$ & & & & & $\checkmark$ & TCE \\
\hline 126. Bowersox, Stank, \& Daugherty, 1999 & & & $\checkmark$ & & & $\checkmark$ & None \\
\hline 127. Escudero et al., 1999 & & $\checkmark$ & $\checkmark$ & & & $\checkmark$ & Modeling \\
\hline 128. Grabowski \& Roberts, 1999 & & $\checkmark$ & & & $\checkmark$ & & None \\
\hline 129. Kouvelis \& Milner, 2002 & $\checkmark$ & & $\checkmark$ & & $\checkmark$ & & Modeing \\
\hline 130. Nooteboom, Berger, \& Noorderhaven, 1997 & $\checkmark$ & & $\checkmark$ & & $\checkmark$ & & TCE \\
\hline 131. Ritchie \& Brindley, 2000 & $\checkmark$ & & $\checkmark$ & & $\checkmark$ & & None \\
\hline 132. Sabri \& Beamon, 2000 & & & & $\checkmark$ & $\checkmark$ & $\checkmark$ & Modeling \\
\hline 133. Sharratt \& Choong, 2002 & & & & $\checkmark$ & & $\checkmark$ & None \\
\hline 134. Tsay, 1999 & & & $\checkmark$ & & & $\checkmark$ & Modeling \\
\hline 135. van der Horst et al., 1998 & & $\checkmark$ & $\checkmark$ & & & $\sqrt{ }$ & None \\
\hline 136. van Mieghem, 1999 & $\checkmark$ & & & & & $\checkmark$ & Modeling \\
\hline
\end{tabular}

The articles show no apparent biases besides the normal scarcity of articles working on the network level. More than half the articles make explicit reference to theory; two articles make reference to transaction cost economics, other six are using modelling.

Combining the themes from the previous sections, and performing the analysis on all the articles across journal categories reveal only one new theme; 'Supply Chain Design'.

Table 9: Themes identified in across journal categories

\begin{tabular}{|l|l|r|}
\hline Theme & Article No & Count \\
\hline Improving Techniques for Operations & $2,6-7,11,19-22,24,26,30,39-41,44-50,52-54,56,58,62-65$, & 49 \\
& $67,70,72-73,75,78,80,85-88,92,96-99,104,113,120$ & 11 \\
\hline Risk Management & $27,30,32,42-43,51,59,68,82,108,121$ & 5 \\
\hline Risk Preference & $89-91,94-95$ & 4 \\
\hline Securing the Supply Chain & $3,34-36$ & 5 \\
\hline Supply Chain Design & $11,33,107,131,135$ & 15 \\
\hline Supply Management & $1,6,15-17,28-29,32,38,42,55,64,69,74,79$ & 7 \\
\hline Vulnerability in Physical Flows & $4-5,8-10,23,31$ & \\
\hline
\end{tabular}

\section{Conclusion}

Judging by the number of articles dealing with improvement of techniques in operations, risk and uncertainty is definitely dealt with on the operational level. A number of articles are dealing with the integration of uncertainty into the operational decision making process: the establishment of planning fences in MRP systems and the determination of planning horizons etc. These articles 
have already had an impact, as most ERP systems today have these techniques built into their standard functionality. Surprisingly, though, is the lack of a thorough and complete integration of RM into the management and design of supply chains. The articles listed above in the theme 'Supply Chain Design' are a starting point, but there is still a long way to go.

\section{Discussion}

The literature study has revealed an absence of RM within SCM. Despite many efforts related to minimizing uncertainty, and assessing the vulnerability of the market and the internal operations, apparently risk has not been perceived as a parameter for supply chain design.

One way of minimizing the vulnerability of the supply chain is to build buffers in all interfaces to other companies, but doing so will cost the company dearly on holding costs in the short run and lack of information in the long run. And it might be argued that at least some of the relationships with the supply chain partners must be non-arms-length to classify as a supply chain member. So, if integrating with the other participants in the network is a characteristic determining the degree or type of supply chain management, how should one choose whom to integrate closely with, and whom should be held at arms length?

\section{Supply Chain Integration}

Lawrence \& Lorsch (1986) define integration as

"the quality of the state of collaboration that exists among departments that are required to achieve unity of effort by the demands of the environment" (Lawrence \& Lorsch, 1986)

While this definition refers to integration internal to a firm or organization, the emphasis here goes beyond the firm and encompasses external entities that are players in a supply chain.

According to Bowersox, Closs, \& Stank (1999) the integration objective can be formulated along six different lines: Customer integration, internal integration, material and service supplier integration, technology and planning integration, measurement integration, and relationship integration.

Similarly, Lee (2000) outlines three dimensions of supply chain integration: information integration, co-ordination and resource sharing, and organisational relationship linkage. Information integration refers to the sharing of information and knowledge among the members in the supply chain, including sales forecasts, production plans, inventory status and promotion plans. Co-ordination and resource sharing refers to the realignment of decisions and responsibility in the 
supply chain. Organisational relationship linkages include communication channels between the members in the supply chain, performance measurement and sharing of common visions and objectives.

In previous research (Bagchi, Skjoett-Larsen, \& Sørensen, 2003) the author has worked with a supply chain integration framework consisting of the following types of integration: process, social and information. Process integration is the co-development of processes or the adjustment of existing routines to match the routines of supply chain partners. Social integration is the contact, e.g. meetings, conferences, phone calls etc. Information integration describes the integration of automated systems, like EDI/XML, ERP-systems etc. The research has shown that the level of integration between European firms in supply chains is still quite low. This is supported by other researchers performing similar research (Bask \& Juga, 2001;Fawcett \& Magnan, 2002).

Arguments for not integrating closer are many. The fear of losing proprietary information on products and processes is a very real threat to many companies, as is the loss of competencies when outsourcing. The integration of administrative systems and processes might cause exit costs to rise, making the termination of the relationship more painful, thereby increasing the risk of competency and quality flaws from suppliers.

Choosing not to integrate closely has corresponding risks, including the loss of business opportunities, the lagging of technological knowledge, sub-optimality in all transactions due to their generic definition, etc.

\section{Further research}

The author intends to integrate RM into SCM by developing a methodology to assess the risk level of each participant in the supply chain and to manage it by altering the type and level of integration between the focal company and the individual partners. The goal of the methodology is to implement stability as a design objective alongside cost and lead time minimization and responsiveness.

\section{Acknowledgements}

The author would like to thank professor Tage Skjøtt-Larsen, Copenhagen Business School and two anonymous reviewers from IJPDLM for useful comments on an earlier version of this manuscript. 


\section{References}

Agrawal, V. \& Seshadri, S. 2000, "Risk intermediation in supply chains", IIE Transactions, vol. 32, no. 9, pp. 819-831.

Albino, V. \& Garavelli, A. C. 1995, "A methodology for the vulnerability analysis of just-in-time production systems", International Journal of Production Economics, vol. 41, no. 1-3, pp. 7180.

Allaire, Y. \& Firsirotsu, M. E. 1989, "Coping with Strategic Uncertainty", Sloan Management Review, vol. 30, no. 3, pp. 7-16.

Arcelus, F. J., Pakkala, T. P. M., \& Srinivasan, G. 2002, "A purchasing framework for B2B pricing decisons and risk-sharing in supply chains", Decision Sciences, vol. 33, no. 4, pp. 645-666.

Bagchi, P. K. \& Skjoett-Larsen, T. 2003a, "Integration of Information Technology and Organizations in a Supply Chain Network", International Journal of Logistics Management, vol. forthcoming.

Bagchi, P. K. \& Skjoett-Larsen, T. 2003b, "Organizational Integration in Supply Chains: A European Survey", Integrated Manufacturing Systems, vol. forthcoming.

Bagchi, P. K., Skjoett-Larsen, T., \& Sørensen, L. B. 2003, "Organizational Integration in Supply Chains," in Proceedings of NOFOMA 2003, J. Juga, ed., Oulu, pp. 11-25.

Baker, K. R. 1986, "Component Buffer Stocks for Uncertainty in Product Mix.", International Journal of Operations \& Production Management, vol. 6, no. 5, pp. 63-71.

Ballestero, E. 2002, "Strict uncertainty: A criterion for moderately pessimistic decision makers", Decision Sciences, vol. 33, no. 1, pp. 87-107.

Ballou, D. P. \& Pazer, H. L. 1987, "Designing Inspection Strategies for Uncertain Environments", Decision Sciences, vol. 18, no. 2, pp. 217-233.

Bartezzaghi, E. \& Verganti, R. 1995, "Managing demand uncertainty through order overplanning", International Journal of Production Economics, vol. 40, no. 2-3, pp. 107-120.

Bartezzaghi, E., Verganti, R., \& Zotteri, G. 1999, "A simulation framework for forecasting uncertain lumpy demand", International Journal of Production Economics, vol. 59, no. 1-3, pp. 499-510.

Bask, A. H. \& Juga, J. 2001, "Semi-integrated Supply Chains: Towards the New Era of Supply Chain Management", International Journal of Logistics: Research and Applications, vol. 4, no. 2, pp. 137-152.

Bechtel, C. \& Jayaram, J. 1997, "Supply Chain Management: A Strategic Perspective", International Journal of Logistics Management, vol. 8, no. 1, pp. 15-34.

Bensaou, M. \& Anderson, E. 1999, "Buyer-Supplier Relations in Industrial Markets: When Do Buyers Risk Making Idiosyncratic Investments?", Organization Science, vol. 10, no. 4, pp. 460-481.

Bernstein, P. L. 1996, "The New Religion of Risk Management", Harvard Business Review, vol. 74, no. 2, pp. 47-55.

Bernstein, P. L. 2001, Against the Gods - the History of Risk. 
Black, F. \& Scholes, M. 1973, "The pricing of options and corporate liabilities", Journal of Political Economy, vol. 81, no. 3, pp. 637-654.

Blanchini, F., Rinaldi, F., \& Ukovich, W. 1996, "A dynamic game model for distribution problems with non-stochastic uncertainty", International Journal of Production Economics, vol. 45, no. 1-3, pp. 479-487.

Borge, D. 2001, The Book of Risk John Wiley \& Sons.

Boronico, J. S. \& Bland, D. J. 1996, "Customer service: the distribution of seasonal food products under risk", International Journal of Physical Distribution and Logistics Management, vol. 26, no. 1, pp. 25-39.

Bowersox, D. J., Stank, T. P., \& Daugherty, P. J. 1999, "Lean Launch: Managing Product Introduction Risk Through Response-Based Logistics", Journal of Product Innovation Management, vol. 16, no. 6, pp. 557-568.

Bowersox, D. J., Closs, D. J., \& Stank, T. P. 1999, 21st Century Logistics: Making Supply Chain Integration a Reality Council of Logistics Management, Oak Brook, IL.

Bowman, E. H. 1980, "A Risk/Return Paradox for Strategic Management", Sloan Management Review, vol. 21, no. 3, pp. 17-31.

Bowman, E. H. 1982, "Risk Seeking by Troubled Firms", Sloan Management Review, vol. 23, no. 4, pp. 33-42.

Brown, S. L. \& Eisenhardt, K. M. 1995, "Product Development: Past Research, Present Findings, and Future Directions", Academy of Management Review, vol. 20, no. 2, pp. 343-378.

Bunn, M. D. \& Liu, B. S.-C. 1996, "Situational Risk in Organizational Buying: A Basis for Adaptive Selling", Industrial Marketing Management, vol. 25, no. 6, pp. 439-452.

Callarman, T. E. \& Hamrin, R. S. 1984, "A Comparison of Dynamic Lot Sizing Rules for Use in a Single Stage MRP System with Demand Uncertainty", International Journal of Operations \& Production Management, vol. 4, no. 2, pp. 39-48.

Callen, J. L. \& Sarath, B. 1995, "Risk aversion, generalized correlation and investment in manufacturing capacities", Journal of Operations Management, vol. 12, no. 3, pp. 225-237.

Carter, J. R., Vickery, S. K., \& D'Itri, M. P. 1993, "Currency Risk Management Strategies for Contracting with Japanese Suppliers", International Journal of Purchasing and Materials Management, vol. 29, no. 3, pp. 19-25.

Christy, D. P. \& Kanet, J. K. 1988, "Open Order Rescheduling in Job Shops with Demand Uncertainty: A Simulation Study", Decision Sciences, vol. 19, no. 4, pp. 801-818.

Clegg, C. \& Fitter, M. 1981, "Organizational and Behavioural Consequences of Uncertainty: A Case Study", Journal of Occupational Behavior, vol. 2, no. 3, pp. 155-175.

Clemons, E. K. 1995, "Using Scenario Analysis to Manage the Strategic Risks of Reengineering", Sloan Management Review, vol. 36, no. 4, pp. 61-71.

Collis, D. 1992, "The Strategic Management of Uncertainty", European Management Journal, vol. 10, no. 2, pp. 125-135.

Cooper, M. C. \& Ellram, L. M. 1993, "Characteristics of Supply Chain Management and the Implications for Purchasing and Logistics Strategy", International Journal of Logistics Management, vol. 4, no. 2, pp. 13-24. 
Copacino, W. C. \& Lapide, L. 1984, "The Impact of Uncertain Transportation Costs on Physical Distribution Planning", Journal of Business Logistics, vol. 5, no. 1, pp. 40-56.

Cozzolino, J. M. 1979, "A New Method for Risk Analysis", Sloan Management Review, vol. 20, no. 3, pp. 53-66.

Denzler, D. R., Boe, W. J., \& Duplaga, E. 1987, "An Experimental Investigation of FMS Scheduling Rules Under Uncertainty", Journal of Operations Management, vol. 7, no. 1-2, pp. 139-151.

Dillinger, A. M., Stein, W. E., \& Mizzi, P. J. 1992, "Risk Averse Decisions in Business Planning", Decision Sciences, vol. 23, no. 4, pp. 1003-1008.

Dolgui, A. \& Ould-Louly, M.-A. 2002, "A model for supply planning under lead time uncertainty", International Journal of Production Economics, vol. 78, no. 2, pp. 145-152.

Escudero, L. F., Galindo, E., Garcia, G., Gomez, E., \& Sabau, V. 1999, "Schumann, a modeling framework for supply chain management under uncertainty", European Journal of Operational Research, vol. 119, no. 1, pp. 14-34.

Etienne, E. C. 1987, "Choosing Optimal Buffering Strategies for Dealing with Uncertainty in MRP", Journal of Operations Management, vol. 7, no. 1-2, pp. 107-120.

Fawcett, S. E. \& Magnan, G. M. 2002, "The rhetoric and reality of supply chain integration", International Journal of Physical Distribution and Logistics Management, vol. 32, no. 5, pp. 339-361.

Fisher, M. L., Hammond, J. H., Obermeyer, W. R., \& Raman, A. 1994, "Making Supply Meet Demand in an Uncertain World", Harvard Business Review, vol. 72, no. 3, pp. 83-93.

Geary, S., Childerhouse, P., \& Towill, D. R. 2002, "Uncertainty and the Seamless Supply Chain", Supply Chain Management Review, vol. 6, no. 4, pp. 52-61.

Ghosh, D. 1994, "Tolerance for ambiguity, risk preference, and negotiator effectiveness", Decision Sciences, vol. 25, no. 2, pp. 263-280.

Ghosh, D. \& Ray, M. R. 1992, "Risk Attitude, Ambiguity Intolerance and Decision Making: An Exploratory Investigation", Decision Sciences, vol. 23, no. 2, pp. 431-444.

Ghosh, D. \& Ray, M. R. 1997, "Risk, ambiguity, and decision choice: Some additional evidence", Decision Sciences, vol. 28, no. 1, pp. 81-104.

Gibson, B. J. \& Hanna, J. B. 2003, "Periodical Usefulness: The U.S. Logistics Educator Perspective", Journal of Business Logistics, vol. 24, no. 1, pp. 221-240.

Gong, L. \& Sun, B. 1995, "Efficiency measurement of production operations under uncertainty", International Journal of Production Economics, vol. 39, no. 1-2, pp. 55-66.

Grabowski, M. \& Roberts, K. 1997, "Risk Mitigation in Large-Scale Systems: Lessons From High Reliability Organizations", California Management Review, vol. 39, no. 4, pp. 152-162.

Grabowski, M. \& Roberts, K. 1999, "Risk Mitigation in Virtual Organizations", Organization Science, vol. 10, no. 6, pp. 704-721.

Graves, S. B. \& Ringuest, J. L. 1991, "Producer's and Consumer's Risk When Proportion Defective Is a Random Variable", Decision Sciences, vol. 22, no. 1, pp. 753-19.

Gupta, D., Gerchak, Y., \& Buzacott, J. A. 1992, "The optimal mix of flexible and dedicated manufacturing capacities: Hedging against demand uncertainty", International Journal of Production Economics, vol. 28, no. 3, pp. 309-319. 
Güllü, R., Ônol, E., \& Erkip, N. 1999, "Analysis of an inventory system under supply uncertainty", International Journal of Production Economics, vol. 59, no. 1-3, pp. 377-385.

Hallikas, J., Virolainen, V.-M., \& Tuominen, M. 2002, "Risk analysis and assessment in network environments: A dyadic case study", International Journal of Production Economics, vol. 78, no. 1, pp. 45-55.

Handfield, R. B. \& Nichols, E. L. 1999, Introduction to Supply Chain Management Prentice Hall, New Jersey.

Harland, C. 1996, "Supply Chain Management: Relationships, Chains and Networks", British Journal of Management, vol. 7, no. Special Issue, pp. 63-80.

Harland, C., Brenchley, R., \& Walker, H. 2003, "Risk in supply networks", Journal of Purchasing and Supply Management, vol. 9, no. 2, pp. 51-62.

Harland, C., Lamming, R., Zheng, J., \& Johnsen, T. E 2001, "A Taxonomy of Supply Networks", Journal of Supply Chain Management, vol. 37, no. 4, pp. 21-27.

Havlena, W. J. \& DeSarbo, W. S. 1991, "On the Measurement of Perceived Consumer Risk", Decision Sciences, vol. 22, no. 4, pp. 927-939.

Hecht, L. \& Morici, P. 1993, "Managing risks in Mexico", Harvard Business Review, vol. 71, no. 4, pp. 32-40.

Henthorne, T. L., LaTour, M. S., \& Williams, A. J. 1993, "How Organizational Buyers Reduce Risk", Industrial Marketing Management, vol. 22, no. 1, pp. 41-48.

Hertz, D. B. \& Thomas, H. 1983, "Decision and Risk Analysis in a New Product and Facilities Planning Problem", Sloan Management Review, vol. 24, no. 2, pp. 17-31.

Hill, A. V. \& Vollmann, T. E. 1986, "Reducing Vendor Delivery Uncertainties in a JIT Environment", Journal of Operations Management, vol. 6, no. 4, pp. 381-392.

Ho, C. \& Carter, P. L. 1994, "Adopting Rescheduling Capability in DRP to Deal with Operational Uncertainty in Logistics Systems", International Journal of Logistics Management, vol. 5, no. 1, pp. 33-42.

Jahre, M. 2003, "Writing Scientific Papers - Some Reflections," in Case Study Research In Logistics, L. Ojala \& O.-P. Hilmola, eds., Turku School of Economics and Business Administration, Turku, pp. 73-82.

Jang, J. \& Liu, C. R. 1993, "Estimating the reduction in labor hours due to a new technology under uncertain demand", International Journal of Production Economics, vol. 29, no. 2, pp. 221222.

Jeunet, J. \& Jonard, N. 2000, "Measuring the performance of lot-sizing techniques in uncertain environments", International Journal of Production Economics, vol. 64, no. 1-3, pp. 197-208.

Johansen, S. G. 1999, "Lot sizing for varying degrees of demand uncertainty", International Journal of Production Economics, vol. 59, no. 1-3, pp. 405-414.

Johnson, M. E. 2001, "Learning From Toys: Lessons In Managing Supply Chain Risk From The Toy Industry", California Management Review, vol. 43, no. 3, pp. 106-124.

Kadipasaoglu, S. N. \& Sridharan, V. 1995, "Alternative approaches for reducing schedule instability in multistage manufacturing under demand uncertainty", Journal of Operations Management, vol. 13, no. 3, pp. 193-211. 
Kelle, P. \& Miller, P. A. 2001, "Stockout risk and order splitting", International Journal of Production Economics, vol. 71, no. 1-3, pp. 407-415.

Korpela, J., Kyläheiko, K., Lehmusvaara, A., \& Tuominen, M. 2002, "An analytical approach to production capacity allocation and supply chain design", International Journal of Production Economics, vol. 78, no. 2, pp. 187-195.

Koutsoukis, N.-S., Dominguez-Ballesteros, B., Lucas, C. A., \& Mitra, G. 2000, "A prototype decision support system for strategic planning under uncertainty", International Journal of Physical Distribution and Logistics Management, vol. 30, no. 7/8, pp. 640-660.

Kouvelis, P. \& Milner, J. M. 2002, "Supply chain capacity and outsourcing decisions: the dynamic interplay of demand and supply uncertainty", IIE Transactions, vol. 34, no. 8, pp. 717-728.

Krishnan, V. \& Ulrich, K. T. 2001, "Product Development Decisions: A Review of the Literature", Management Science, vol. 47, no. 1, pp. 1-21.

Krueger, N. J. \& Dickson, P. R. 1994, "How believing in ourselves increases risk taking: Perceived Self-Efficacy and Opportunity Recognition", Decision Sciences, vol. 25, no. 3, pp. 385-400.

Lau, A. H.-L., Lau, H.-S., \& Willett, K. D. 2000, "Demand uncertainty and returns policies for a seasonal product: An alternative model", International Journal of Production Economics, vol. 66, no. 1, pp. 1-12.

Lau, H.-S. 1989, "Toward An Inventory Control System Under Non-Normal Demand And LeadTime Uncertainty", Journal of Business Logistics, vol. 10, no. 1, pp. 88-103.

Lawrence, P. R. \& Lorsch, J. W. 1986, Organization and Environment: Managing Differentiation and Integration Harvard Business School Press, Boston, MA.

Lee, D. Y. 1997, "The impact of poor performance on risk-taking attitudes: A longitudinal study with a PLS causal modeling approach", Decision Sciences, vol. 28, no. 1, pp. 59-80.

Lee, H. L. 2000, "Creating value through supply chain integration", Supply Chain Management Review, vol. 4, no. 4, pp. 30-36.

Lee, H. L. 2002, "Aligning Supply Chain Strategies with Product Uncertainties", California Management Review, vol. 44, no. 3, pp. 105-119.

Lee, H. L. \& Wolfe, M. 2003, "Supply Chain Security Without Tears", Supply Chain Management Review, vol. 7, no. 1, pp. 12-20.

Lewis, M. A. 2003, "Cause, consequence and control: towards as theoretical and practical model of operational risk", Journal of Operations Management, vol. 21, no. 2, pp. 205-224.

Lin, N.-P. \& Krajewski, L. 1992, "A Model for Master Production Scheduling in Uncertain Environments", Decision Sciences, vol. 23, no. 4, pp. 839-861.

Lonsdale, C. 1999, "Effectively managing vertical supply relationships: a risk management model for outsourcing", Supply Chain Management: An International Journal, vol. 4, no. 4, pp. 176183.

Markowitz, H. 1952, "Portfolio Selection", Journal of Finance, vol. 7, no. 1, pp. 77-91.

Marsh, T. A. \& Swanson, D. S. 1984, "Risk-Return Tradeoffs for Strategic Management", Sloan Management Review, vol. 25, no. 3, pp. 35-51.

Marshall, R. M. \& Narasimhan, R. 1989, "Risk-Constrained Information Choice", Decision Sciences, vol. 20, no. 4, pp. 677-684. 
Martha, J. \& Subbakrishna, S. 2002, "Targeting a Just-In-Case Supply Chain for the Ine vitable Next Disaster", Supply Chain Management Review, vol. 6, no. 5, pp. 18-23.

Matsuura, H., Tsubone, H., \& Kataoka, K. 1995, "Comparison between simple infinite loading and loading considering a workload status under uncertainty in job operation times", International Journal of Production Economics, vol. 40, no. 1, pp. 45-55.

Meldrum, M. J. \& Millman, A. F. 1991, "Ten Risks in Marketing High-Technology Products", Industrial Marketing Management, vol. 20, no. 1, pp. 43-50.

Menachof, D. 1996, "Risk Manage ment Methods for the Liner Shipping Industry: The Response to Customer Service Demands for Simplified Tariffs", Journal of Business Logistics, vol. 17, no. 1, pp. 259-290.

Mentzer, J. T., Dewitt, W., Keebler, J. S., Min, S., Nix, N. W., Smith, C. D., \& Zacharia, Z. G. 2001, "Defining Supply Chain Management", Journal of Business Logistics, vol. 22, no. 2, pp. $1-25$.

Meshkat, H. \& Ballou, R. H. 1996, "Warehouse Location with Uncertain Stock Availability", Journal of Business Logistics, vol. 17, no. 2, pp. 197-216.

Muntslag, D. R. 1994, "Profit and risk evaluation in customer driven engineering and manufacturing", International Journal of Production Economics, vol. 36, no. 1, pp. 97-107.

Murthy, D. N. P. \& Ma, L. 1991, "MRP with uncertainty: a review and some extensions", International Journal of Production Economics, vol. 25, no. 1-3, pp. 51-64.

Newman, W. R., Hanna, M., \& Maffei, M. J. 1993, "Dealing with the Uncertainties of Manufacturing: Flexibility, Buffers and Integration", International Journal of Operations \& Production Management, vol. 13, no. 1, pp. 19-34.

Noori, A. H. \& Keller, G. 1986, "The Lot-Size Reorder-Point Model with Upstream-Downstream Uncertainty", Decision Sciences, vol. 17, no. 3, pp. 285-291.

Nooteboom, B., Berger, H., \& Noorderhaven, N. G. 1997, "Effects of Trust and Governance on Relational Risk", The Academy of Management Journal, vol. 40, no. 2, pp. 308-338.

Noy, E. \& Ellis, S. 2003, "Corporate Risk Strategy: Does it Vary Across Business Activities?", European Management Journal, vol. 21, no. 1, pp. 119-128.

Oliver, R. K. \& Webber, M. D. 1982, "Supply Chain Management: logistics catches up with strategy", Outlook.

Ottesen, G. G. \& Gronhaug, K. 2002, "Market orientation and uncertain supply in upstream markets: an exploratory study", European Journal of Purchasing \& Supply Management, vol. 8, no. 4, pp. 209-219.

Pagell, M. \& Krause, D. R. 1999, "A multiple-method study of enviromnental uncertainty and manufacturing flexibility", Journal of Operations Management, vol. 17, no. 3, pp. 307-325.

Petrovic, D. 2001, "Simulation of supply chain behaviour and performance in an uncertain environment", International Journal of Production Economics, vol. 71, no. 1-3, pp. 429-438.

Petrovic, R. \& Petrovic, D. 2001, "Multicriteria ranking of inventory replenishment policies in the presence of uncertainty in customer demand", International Journal of Production Economics, vol. 71, no. 1-3, pp. 439-446.

Pilling, B. K. \& Zhang, L. 1992, "Cooperative Exchange: Rewards and Risks", International Journal of Purchasing and Materials Management, vol. 28, no. 2, pp. 2-9. 
Polk, R., Plank, R. E., \& Reid, D. A. 1996, "Technical Risk and New Product Success: An Empirical Test in High Technology Business Markets", Industrial Marketing Management, vol. 25 , no. 6 , pp. 531-543.

Quelch, J. A., Neslin, S. A., \& Olson, L. B. 1987, "Opportunities and Risks of Durable Goods Promotion", Sloan Management Review, vol. 28, no. 2, pp. 27-38.

Ritchie, B. \& Brindley, C. 2000, "Disintermediation, disintegration and risk in the SME global supply chain", Management Decision, vol. 38, no. 8, pp. 575-583.

Sabri, E. H. \& Beamon, B. M. 2000, "A multi-objective approach to simultaneous strategic and operational planning in supply chain design", Omega, vol. 28, no. 5, pp. 581-598.

Schary, P. B. \& Skjoett-Larsen, T. 2001, Managing the Global Supply Chain, 2 edn, Handelshøjskolens Forlag A/S, København.

Schill, R. L. 1985, "Managing Risk in Contract Pricing with Multiple Incentives", Industrial Marketing Management, vol. 14, no. 1, pp. 1-16.

Schmitt, T. G. 1984, "Resolving Uncertainty in Manufacturing Systems", Journal of Operations Management, vol. 4, no. 4, pp. 331-345.

Schwarz, L. B. \& Weng, Z. K. 2000, "The Design of a JIT Supply Chain: The Effect of Leadtime Uncertainty on Safety Stock", Journal of Business Logistics, vol. 21, no. 2, pp. 231-253.

Sells, B. 1994, "What Asbestos Taught Me About Managing Risk", Harvard Business Review, vol. 72, no. 2, pp. 76-89.

Sharratt, P. N. \& Choong, P. M. 2002, "A life-cycle framework to analyse business risk in process industry projects", Journal of Cleaner Production, vol. 10, no. 5, pp. 479-493.

Sheffi, Y. 2001, "Supply Chain Management under the Threat of International Terrorism", International Journal of Logistics Management, vol. 12, no. 2, pp. 1-11.

Simchi-Levi, D., Snyder, L., \& Watson, M. 2002, "Strategies for Uncertain Times", Supply Chain Management Review, vol. 6, no. 1, pp. 11-12.

Simons, R. 1999, "How Risky is Your Company?", Harvard Business Review, vol. 77, no. 3, pp. 85-94.

Smeltzer, L. R. \& Siferd, S. P. 1998, "Proactive Supply Management: The Management of Risk", International Journal of Purchasing and Materials Management, vol. 34, no. 1, pp. 38-45.

Speh, T. W. \& Wagenheim, G. D. 1978, "Demand and Lead-Time Uncertainty: The Impacts on Physical DIstribution Performance and Management", Journal of Business Logistics, vol. 1, no. 1, pp. 95-113.

Sridharan, V. \& Berry, W. L. 1990, "Freezing The Master Production Schedule Under Demand Uncertainty", Decision Sciences, vol. 21, no. 1, pp. 97-120.

Stevens, G. C. 1989, "Integrating the Supply Chain", International Journal of Physical Distribution and Materials Management, vol. 19, no. 8, pp. 3-8.

Svensson, G. 2000, "A conceptual framework for the analysis of vulnerability in supply chains", International Journal of Physical Distribution and Logistics Management, vol. 30, no. 9, pp. 731-749.

Svensson, G. 2001, "Firms' Preventive Activities and the Occurence of Disturbances in the Inbound and Outbound Logistics Flows", International Journal of Logistics: Research and Applications, vol. 4, no. 2, pp. 207-236. 
Svensson, G. 2002a, "A conceptual framework of vulnerability in firms' inbound and outbound logistics flows", International Journal of Physical Distribution and Logistics Management, vol. 32, no. 2, pp. 110-134.

Svensson, G. 2002b, "A typology of vulnerability scenarios towards suppliers and customers in supply chains based upon perceived time and relationship dependencies", International Journal of Physical Distribution and Logistics Management, vol. 32, no. 3, pp. 168-187.

Svensson, G. 2002c, "Dyadic Vulnerability in Companies' Inbound and Outbound Logistics Flows", International Journal of Logistics: Research and Applications, vol. 5, no. 1, pp. 13-43.

Svensson, G. 2002d, "Vulnerability scenarios in marketing channels", Supply Chain Management: An International Journal, vol. 7, no. 5, pp. 322-333.

Swoveland, C. 1987, "Risk Analysis of Regulatory Options for the Transport of Dangerous Commodities by Rail", Interfaces, vol. 17, no. 4, pp. 90-107.

Tan, K. C. 2001, "A framework of supply chain management literature", European Journal of Purchasing \& Supply Management, vol. 7, no. 1, pp. 39-48.

Tang, O. \& Grubbström, R. W. 2002, "Planning and replanning the master production schedule under demand uncertainty", International Journal of Production Economics, vol. 78, no. 3, pp. 323-334.

Templin, C. R. \& Noffsinger, K. R. 1994, "An Assessment of the Role of Technical and Risk Evaluation Factors in Defense Source Selection Decisions", International Journal of Purchasing and Materials Management, vol. 30, no. 4, pp. 37-43.

Treleven, M. \& Schweikhart, S. B. 1988, "A risk/benefit analysis of sourcing strategies: single vs. multiple sourcing", Journal of Operations Management, vol. 7, no. 4, pp. 93-114.

Tsay, A. A. 1999, "The Quantity Flexibility Contract and Supplier-Customer Incentives", Management Decision, vol. 45, no. 10, pp. 1339-1358.

Tullous, R. \& Munson, J. M. 1991, "Trade-offs Under Uncertainty: Implications for Industrial Purchasers", International Journal of Purchasing and Materials Management, vol. 27, no. 3, pp. 24-31.

van der Horst, J. G. A. J. \& Beulens, A. J. M. 2002, "Identifying sources of uncertainty to generate supply chain redesign strategies", International Journal of Physical Distribution and Logistics Management, vol. 32, no. 6, pp. 409-430.

van der Horst, J. G. A. J., Beulens, A. J. M., de Wit, W., \& van Beek, P. 1998, "Supply Chain Management in Food Chains: Improving Performance by Reducing Uncertainty", International Transactions in Operational Research, vol. 5, no. 6, pp. 487-499.

van der Vaart, J. T., de Vries, J., \& Wijngaard, J. 1996, "Complexity and uncertainty of materials procurement in assembly situations", International Journal of Production Economics, vol. 46-47, pp. 137-152.

van Dorp, J. R. \& Duffey, M. R. 1999, "Statistical dependence in risk analysis for project networks using Monte Carlo methods", International Journal of Production Economics, vol. 58, no. 1, pp. 17-29.

van Mieghem, J. A. 1999, "Coordinating Investment, Production, and Subcontracting", Management Decision, vol. 45, no. 7, pp. 954-971.

Vidal, C. J. \& Goetschalkx, M. 2000, "Modeling the Effect of Uncertainties on Global Logistics Systems", Journal of Business Logistics, vol. 21, no. 1, pp. 95-120. 
Vokurka, R. J. 1996, "The relative importance of journals used in operations management research A citation analysis", Journal of Operations Management, vol. 14, no. 4, pp. 345-355.

Vörös, J. 1999, "On the risk-based aggregate planning for seasonal products", International Journal of Production Economics, vol. 59, no. 1-3, pp. 195-201.

Walker, G. 1988, "Strategic Sourcing, Vertical Integration, and Transaction Cost", Interfaces, vol. 18 , no. 3, pp. 62-73.

Watkins, M. D. \& Bazerman, M. H. 2003, "Predictable Surprises: The Disasters You Should Have Seen Coming", Harvard Business Review, vol. 81, no. 3, pp. 72-80.

Wedel, M. \& DeSarbo, W. S. 1993, "A Latent Class Binomial Logit Methodology for the Analysis of Paired Comparison Choice Data: An Application Reinvestigating the Determinants of Perceived Risk", Decision Sciences, vol. 24, no. 6, pp. 1157-1170.

Weng, Z. K. 1999, "Risk-pooling over demand uncertainty in the presence of product modularity", International Journal of Production Economics, vol. 62, no. 1-2, pp. 75-85.

Westbrook, K. W. 1996, "Risk Coordinative Maneuvers During Buyer-Seller Negotiations", Industrial Marketing Management, vol. 25, no. 4, pp. 283-292.

Wilding, R. 1998, "The supply chain complexity triangle - Uncertainty generation in the supply chain", International Journal of Physical Distribution and Logistics Management, vol. 28, no. 8, pp. 599-616.

Wood, W. R. 1985, "The Risks On Reliance On The Uniform Railroad Costing System", Journal of Business Logistics, vol. 6, no. 2, pp. 142-158.

Wright, G. 1980, "Purchasing, Risk and Logistics: A Neglected Combination?", International Journal of Operations \& Production Management, vol. 1, no. 1, pp. 47-58.

Zaidman, B. 1994, "Market vulnerability in the process industries", International Journal of Production Economics, vol. 34, no. 1, pp. 57-64.

Zhao, Z. \& Lee, T. S. 1993, "Freezing the master production schedule for material requirements planning systems under demand uncertainty", Journal of Operations Management, vol. 11, no. 2, pp. 185-205.

Zimmer, K. 2002, "Supply chain coordination with uncertain just-in-time delivery", International Journal of Production Economics, vol. 77, no. 1, pp. 1-15.

Zinszer, P. H. 1983, "Inventory Costing: A Return On Inventory Approach To Differentiating Inventory Risk", Journal of Business Logistics, vol. 4, no. 2, pp. 20-39.

Zsidisin, G. 2003, "Managerial Perceptions of Supply Risk", Journal of Supply Chain Management, vol. 39, no. 1, pp. 14-25.

Zsidisin, G. A., Panelli, A., \& Upton, R. 2000, "Purchasing organization involvement in risk assessments, contingency plans, and risk management: an exploratory study", Supply Chain Management: An International Journal, vol. 5, no. 4, pp. 187-197.

Zsidisin, G. \& Ellram, L. M. 2003, "An Agency Theory Investigation of Supply Risk Management", Journal of Supply Chain Management, vol. 39, no. 3, pp. 15-27.

Zäpfel, G. 1996, "Production planning in the case of uncertain individual demand - Extension for an MRP II concept", International Journal of Production Economics, vol. 46-47, pp. 153-164. 


\section{Working Papers from the Department of Operations Management}

01/1998 Jens Leth Hougaard, Bezalel Peleg, Lars Thorlund-Petersen:

On the Set of Lorenz-maximal Imputations in the Core of a Balanced Game

Oktober 1998. 23 pp. DKK 45,-. (International Journal of Game Theory, 30,147-165, 2001).

02/1998 Eric Bentzen:

Hjemmebanefordel i "Faxe-Kondi ligaen"

November 1998. 10 pp. DKK 45,-

03/1998 Peter Bogetoft, Jens Leth Hougaard:

Efficiency Evaluations Based on Potential (Non-Proportional) Improvements

November 1998. 19 pp. DKK 45,-. (Journal of Productivity Analysis 12, 233-247, 1999).

4/1998 Tage Skjøtt-Larsen:

Interorganizational Relations from a Supply Chain Management Point of View

December 1998. 23 pp. DKK 45,-. (Logistik Management 1, 96-108, 1999).

05/1998 Peter Neergaard, Bettina Klamer, Martha Poulsen:

Kvalitet og miljø i danske virksomheder

December 1998. 50 pp. DKK 225,-

06/1998 Bøje Larsen, Tord Häversjö:

The Year 2000 Problem of ISO 9000: Will the Quality Standards Survive the Proposed Year 2000 Revision?

December 1998. 18 pp. DKK 45,-

01/1999 Jens Leth Hougaard, Lars Thorlund-Petersen:

Mixed Serial Cost Sharing

February 1999. 28 pp. DKK 45,-. (Mathematical Social Sciences, 41, 51-68, 2001).

02/1999 Jens Leth Hougaard, Lars Thorlund-Petersen:

The Stand-Alone Test and Decreasing Serial Cost Sharing

March 1999. 11 pp. DKK 45,-. (Economic Theory 16, 245-258, 2000).

03/1999 John K. Christiansen, Morten Thanning Vendelø:

The Role of Reputation Building in International R\&D Projekt Coorpeeration

June 1999. 22 pp. DKK 45,-

04/1999 Poul Erik Christiansen, Arnold Maltz:

Outsourcing Behavior in Medium-Sized Danish Manufacturers

September 1999. 33 pp. DKK 45,-. (Printed in Building New Bridges in Logistics. Lund University Proceedings. Nofoma 1999).

05/1999 Poul Erik Christiansen:

Vendor Managed Logistics

October 1999. 15 pp. DKK 45,-(Building New Bridges in Logistics. Lund Universitet.

Proceedings Nofoma 1999).

06/1999 Poul Erik Christiansen:

Quality Management of the Logistics Bachelor Program at Copenhagen Business School

October 1999. 20 pp. DKK 45,-

07/1999 Jens Leth Hougaard, Mich Tvede:

Benchmark Selection: An Axiomatic Approach

December 1999. 15 pp. DKK 45,- (To appear in European Journal of Operational Research) 
01/2000 Poul Erik Christiansen, Jens Overø:

Outsourcing of Sypply Activities in Medium Sized Danish Manufacturers

June 2000. 17 pp. DKK 45,-

02/2000 Eric Bentzen:

Exchange Rate Volatility

June 2000. 14 pp. DKK 45,-

03/2000 Eric Bentzen, Peter Sellin:

The Intertemporal Capital Asset Pricing Model with Returns that Follow Poisson Jump-

Diffusion Processes (To appear in European Journal of Finance)

September 2000. 26 pp. DKK 45,-

04/2000 Lars Peter Østerdal, Jens Nath, Søren Samsøe:

On the Empirical Evidence of Mean Reversion in the Danish Stock Market

September 2000. 24 pp. DKK 45,-

05/2000 Alexander S. Ptuskin, Eugenia A. Belova:

The Qualitative Estimate of Investment Projects Risk

November 2000, 23 pp. DKK 45,-

06/2000 Alexander S. Ptuskin, Eugenia A. Belova:

Supplier Selection Using Fuzzy Sets

November 2000. 15 pp. DKK 45,-

07/2000 Tahir Galperin:

Analysis of Existing Approaches to Project Management Abroad and Study of their Possible Application in Conditions of Russia

December 2000. 43 pp. DKK 45,-

08/2000 Britta Gammelgaard, Paul D. Larson:

The Logistics Triad: Barriers and Facilitators

December 2000. 30 pp. DKK 45,-

01/2001 Heine Thorsgaard Larsen:

At læse Latour

- fra social konstruktivist til anti-kantianist

April 2001. 52 pp. DKK 45,-

02/2001 Peter Neergaard, Mette Andersen:

Integrated Management Systems in SMEs. A case study approach

April 2001. 94 pp. DKK 85,-

03/2001 Poul Erik Christiansen, Arnold Maltz:

Good Supply Chain Practices in Denmark:

Seven Cases from the industry

June 2001. 46 pp. DKK 45,-

04/2001 Jens Leth Hougaard, Lars Thorlund-Petersen:

Bankruptcy Rules, Inequality, and Uncertainty

August 2001. 22 pp. DKK 45,-

05/2001 John K. Christiansen:

Styring og organisering af projekt-, produkt- og IT-udvikling: Udviklinger og perspektiver July 2001. 32 pp. DKK 45,- 
Organizational Integration in Supply Chains

December 2001. 21 pp. DKK 45,-

07/2001 Prabir K. Bagchi, Tage Skjoett-Larsen:

Challenges of Integration in a Supply Chain Network

December 2001. 36 pp. DKK 45,-

08/2001 Herbert Kotzab, Tage Skjoett-Larsen:

Interorganizational Theories behind Supply Chain Management

December 2001. 27 pp. DKK 45,-

01/2002 Lars Thorlund-Petersen:

Global Convergence of Newton's Method on an Interval

June 2002. DKK 45,-

02/2002 Evgenia A. Belova, Tage Skjoett-Larsen:

Supplier Performance Evaluation Base don a Portfolio Approach

July 2002. 29 pp. DKK 45,-

01/2003 Britta Gammelgaard, Eric Bentzen, Mette Aagaard Andreassen:

Benchmarking Danish Industries, Supply Chain Management

October 2003. 13 pp. DKK 45,-

02/2003 Juliana Hsuan Mikkola

Product Architecture Modularity Strategies: Toward A General Theory

October 2003, 45 pp. DKK 45,-

03/2003 Lars B. Sørensen, Lisa L. Holst

The Evolution of Click-n-Mortar. E-tailing In Denmark

December 2003, 14 pp. DKK 45,-

01/2004 Lars B. Sørensen

The design of supply chains: a literature study and a preliminary model March 2004, 22 pp. DKK 45,-

02/2004 Lars B. Sørensen

How risk and uncertainty is used in Supply Chain Management: a literature study March 2004, 24 pp. DKK 45,- 